\title{
RADIOCARBON CALIBRATION BEYOND THE DENDROCHRONOLOGY RANGE
}

\author{
Mordechai Stein $^{1} \bullet$ Steven L Goldstein ${ }^{2}$ Alexandra Schramm ${ }^{3}$ \\ ABSTRACT. The radiocarbon timescale has been calibrated by dendrochronology back to $11.8 \mathrm{ka}$ cal $\mathrm{BP}$, and extended to \\ $14.8 \mathrm{ka}$ cal BP using laminated marine sediments from the Cariaco Basin. Extension to nearly $23.5 \mathrm{ka} \mathrm{cal} \mathrm{BP}$ is based on com- \\ parison between ${ }^{14} \mathrm{C}$ and U-Th ages of corals. Recently, attempts to further extend the calibration curve to $>40 \mathrm{kyr}$ are based \\ on laminated sediments from Lake Suigetsu, Japan, foraminifera in North Atlantic sediments, South African cave deposits, \\ tufa from Spain, and stalagmites from the Bahamas. Here we compare these records with a new comparison curve obtained \\ by ${ }^{234} \mathrm{U}-{ }^{230} \mathrm{Th}$ ages of aragonite deposited at Lake Lisan (the last Glacial Dead Sea). This comparison reveals broad agreement \\ for the time interval of 20-32 ka cal BP, but the data diverge over other intervals. All records agree that $\Delta^{14} \mathrm{C}$ values range \\ between $\sim 250-450 \%$ at $20-32 \mathrm{ka}$ cal BP. For ages $>32 \mathrm{ka}$ cal BP, the Lake Suigetsu data indicate low $\Delta^{14} \mathrm{C}$ values of less than \\ $200 \%$ and small shifts. The other records broadly agree that $\Delta^{14} \mathrm{C}$ values range between $\sim 250$ and $600 \%$ at $32-39 \mathrm{ka}$ cal BP. \\ At $\sim 42 \mathrm{ka}$ cal BP, the North Atlantic calibration shows low $\Delta^{14} \mathrm{C}$ values, while the corals, Lisan aragonites, and the Spanish \\ tufa indicate a large deviations of 700-900\%. This age is slightly younger than recent estimates of the timing of the Laschamp \\ Geomagnetic Event, and are consistent with increased ${ }^{14} \mathrm{C}$ production during this event.
}

\section{INTRODUCTION}

Radiocarbon is the most important chronometer used for the late Pleistocene and Holocene, with applications to a range of disciplines including earth sciences, archaeology, and anthropology. However, ages in ${ }^{14} \mathrm{C}$ years are not equal to calendar years because the ${ }^{14} \mathrm{C}$ activity in the atmosphere has varied with time, and great efforts are underway to generate a calibration to calendar ages (Stuiver and van der Plicht 1998, and references therein). A precise calibration of the ${ }^{14} \mathrm{C}$ time scale has been established based on dendrochronology to 11.8 ka cal BP (Becker and Kromer 1991; Björck et al. 1996; Kromer and Spurk 1998). The calibration has been extended to $14.5 \mathrm{ka}$ cal BP by counting of laminated marine sediments (Hughen et al. 1998), and by U-series dating of corals (Bard et al. 1998; Burr et al. 1998).

Beyond $14.5 \mathrm{ka}$ cal BP, calibration can be extended semi-continuously to $23.5 \mathrm{ka}$ cal BP by U-series dating of corals (Stuiver and van der Plicht 1998). Bard et al. $(1990,1998)$ showed that ${ }^{14} \mathrm{C}$ ages are $\sim 3$ ka younger than calendar ages at $\sim 23.5 \mathrm{ka}$ cal BP. Over the time interval of $24-60 \mathrm{ka}$ cal BP, which includes most of the last Glacial period, there have been major changes in the Earth's climate, and secular variations and short-term excursions in the Earth's magnetic field intensity, all of which can affect the atmospheric ${ }^{14} \mathrm{C}$ activity (cf. Mazaud et al. 1991; Tric et al. 1992; Edwards et al. 1993 Laj et al. 1996). Bard et al. $(1990,1998)$ report two additional coral calibration points, at $\sim 30$ and $\sim 41 \mathrm{ka}$ cal BP. At these times the age differences are even higher, with ${ }^{14} \mathrm{C}$ ages younger than calendar ages, and age differences are $\sim 3-4$ and $\sim 4-6 \mathrm{ka}$, respectively.

Some recent studies have tried to fill the gaps. Kitagawa and van der Plicht (1998a, 1998b) report a ${ }^{14} \mathrm{C}$ age calibration to $45 \mathrm{ka}$ cal BP based on laminated sediments from Lake Suigetsu, Japan. Voelker et al. (1998) report a calibration to $53 \mathrm{ka}$ cal BP using a chronology based on cross-calibration of planktonic foraminiferal stable isotope ratios in North Atlantic cores with the Greenland GISP2 ice core record. Vogel and Kronfeld (1997) report some U-Th ages obtained by $\alpha$-counting of South African stalagmites. Richards et al. (1999) compared ${ }^{14} \mathrm{C}$ with ${ }^{234} \mathrm{U}^{-230} \mathrm{Th}$ and ${ }^{235} \mathrm{U}-231 \mathrm{~Pa}$ ages mea-

\footnotetext{
${ }^{1}$ Corresponding author. Institute of Earth Sciences, The Hebrew University, Givat Ram, Jerusalem, 91904, Israel.

Email: motis@vms.huji.ac.il.

${ }^{2}$ Lamont-Doherty Earth Observatory and Department of Earth and Environmental Sciences, Columbia University, Palisades NY 10964, USA

${ }^{3}$ Max-Planck-Institut für Chemie, Postfach 3060, D-55020 Mainz, Germany
} 
sured by thermal ionization mass spectrometry (TIMS) on stalagmites from the Bahamas. Bischoff et al. (1994) reported a calibration point at $\sim 40 \mathrm{ka} \mathrm{cal} \mathrm{BP}$ from U-Th dating by TIMS of a tufa in Spain.

Construction of a precise calendar age calibration becomes more difficult with increasing age. Problems include higher absolute errors on determinations of the calendar ages with increasing age, and the large influence of small amounts of sample contamination with fossil or recent carbon on the ${ }^{14} \mathrm{C}$ ages. For example, the possibility of unrecognized gaps or other complications in varve counting (Kitagawa and van der Plicht 1998b), or ambiguities in stable isotope cross-correlations between core records (Guyodo and Valet 1996), make dating by a method using radioactive decay desirable. On the other hand, open system behavior, uncertainty of corrections for initial ${ }^{230} \mathrm{Th}$ in samples, can affect the accuracy of the ${ }^{234} \mathrm{U}_{-}{ }^{230} \mathrm{Th}$ radioactive time clock. Ultimately, comparisons of different records and methods are necessary for a credible calibration from $23.5 \mathrm{ka}$ cal BP to the analytical limits of ${ }^{14} \mathrm{C}$ determinations.

Recently, we used a calendar chronology based on ${ }^{234} \mathrm{U}^{230} \mathrm{Th}$ dating by TIMS of aragonitic sediments deposited from Lake Lisan, the last glacial precursor of the Dead Sea, to extend the ${ }^{14} \mathrm{C}$ time scale calibration to $>40 \mathrm{kyr}$ (Schramm et al. 2000). In this paper we summarize the results of the Lisan study and compare the Lisan calibration curve to the other schemes described in the literature.

\section{METHODS}

\section{U-Series Dating by Mass Spectrometry}

U-series dating by mass spectrometry has become an important means to obtain precise ages of late Quaternary corals (cf. Edwards et al. 1987; Stein et al. 1993), continental sediments such as vein calcite (Winograd et al. 1992), and cave deposits (Kaufman et al. 1998). Obtaining precise U-series ages on continental carbonate sediments has been problematic, because they typically contain significant amounts of non-authogenic $\mathrm{U}$ and $\mathrm{Th}$, which must be considered in age evaluations (Bischoff and Fitzpatrick 1991; Kaufman 1993; Ku and Liang 1984; Luo and Ku 1991). This situation contrasts with corals, for example, which typically have negligible amounts of initial Th, and thus ages are determined simply by assuming that all the ${ }^{230} \mathrm{Th}$ in a sample is derived from the ${ }^{238} \mathrm{U}$ and ${ }^{234} \mathrm{U}$ (cf. Edwards et al. 1987; Chen et al. 1991; Stein et al. 1993).

There were major efforts made during the late 1980s, through drilling of coral reefs, to obtain samples that cover the time interval beyond the dendrochronology range. These include off-shore drilling at Barbados (Fairbanks 1989), and on-shore drilling in the Huon Peninsula, Papua New Guinea (Chappell and Polack 1990). Bard and colleagues dated the Barbados cores by ${ }^{14} \mathrm{C}$ and the TIMS Useries method, extending the calibration curve back to $\sim 22 \mathrm{ka}$ (Bard et al 1990). Their results were later augmented by samples from Tahiti, and Mururoa (Bard et al. 1998). The Huon core was used for ${ }^{14} \mathrm{C} / \mathrm{U}$-series age comparison in a continuous interval between 11,000 and $7000 \mathrm{yr}$ (Edwards et al. 1993). This core yielded similar results to the Barbados record, except for the interval of the Younger Dryas Event. The Huon core indicates an abrupt offset between the ${ }^{14} \mathrm{C}$ and U-series ages during the later part and after the Younger Dryas Event, suggesting a large drop in the atmospheric ${ }^{14} \mathrm{C} /{ }^{12} \mathrm{C}$. The integrity of the measured ages for corals is evaluated on the basis of the initial ${ }^{238} \mathrm{U} /$ ${ }^{238} \mathrm{U}$ activity, which should be the same as seawater (1.144 \pm 0.007 ; Chen et al. 1986). The major unknown in using corals for ${ }^{14} \mathrm{C}$ calibration is changes in the marine carbon reservoir. The present day correction is $\sim 400 \mathrm{yr}$, and this figure is assumed for fossil corals as well (Bard et al. 1990, 1998; Edwards et al. 1993; Hughen et al. 1998). 


\section{RESULTS}

\section{${ }^{234} \mathrm{U}-{ }^{230} \mathrm{Th}$ and ${ }^{14} \mathrm{C}$ ages of Lisan Sediments}

Laminated lake sediments are another candidate for calibrating the ${ }^{14} \mathrm{C}$ timescale by ${ }^{234} \mathrm{U}-{ }^{230} \mathrm{Th}$ dating. Schramm et al. (2000a, 2000b) reported TIMS ${ }^{234} \mathrm{U}^{230} \mathrm{Th}$ and ${ }^{14} \mathrm{C}$ ages within a 40 -m-thick measured and described section of the Lisan Formation. The ages range from 70-17 ka, thus spanning a large portion of the last Glacial period. The U-series analyses were made on aragonite from laminated sediments, which can be dated both by U-series and ${ }^{14} \mathrm{C}$ techniques. The Lisan Formation is exposed along the Jordan-Dead Sea Valley. The aragonites precipitated from the surface water and are preserved in their primary state. They have high $U$ concentrations $(\approx 3 \mathrm{ppm})$ and are often free of detritus (based on XRD and chemical analyses) and thus appear to be excellent candidates for ${ }^{234} \mathrm{U}$ ${ }^{230} \mathrm{Th}$ dating. The ${ }^{234} \mathrm{U}-{ }^{230} \mathrm{Th}$ ages that were obtained for the Lisan aragonite are based on analysis of two or more samples taken from individual laminae within a few centimeters of each other. The ${ }^{234} \mathrm{U}-$ ${ }^{230} \mathrm{Th}$ ages were determined for groups of samples from the same stratigraphic level by isochrons, and were also calculated for each individual sample. The "single sample" ages are based on corrections for small detrital contributions of the $\mathrm{U}$ and $\mathrm{Th}$ and for initial aqueous ${ }^{230} \mathrm{Th}$. The presence of an aqueous Th component was deduced from covariations of Th concentrations with $\mathrm{Nb}, \mathrm{Zr}$, and $\mathrm{Fe}$ (that is, insoluble trace elements indicating detritus in the samples). These covariations indicated that when the "detrital" element concentrations equaled zero, indicating pure aragonite, there was a residual Th concentration of $0.07-0.1 \mathrm{ppm}$. The correction used for initial Th is based on a modern aragonite collected from the Dead Sea containing negligible detritus but with $0.06 \mathrm{ppm}$ Th and an apparent ${ }^{234} \mathrm{U}-{ }^{230} \mathrm{Th}$ age of $\sim 2500 \mathrm{yr}$. Both the isochron and the single sample ages show excellent internal consistency and agreement with the stratigraphic order of the section. The aragonite ages range from $67 \mathrm{ka}$ cal BP at $2 \mathrm{~m}$ above the base of the section, to $\sim 19 \mathrm{ka}$ cal BP at $\sim 2 \mathrm{~m}$ beneath the top of the measured and described section at Perazim Valley near the southeastern end of the Dead Sea. Detailed discussion of the geochronological methods are given elsewhere (Schramm et al. 2000a, 2000b).

The validity of ${ }^{14} \mathrm{C}$ ages of aragonites depends on the correct assessment of the degree of equilibrium between the precipitating $\mathrm{CaCO}_{3}$ and atmospheric $\mathrm{CO}_{2}$. Waters flowing over carbonate terrains like the Judean Mountains west of the Jordan-Arava Valley, or percolating through carbonate aquifers, may contain substantial amounts of fossil carbon. If this carbon becomes incorporated into the aragonite, the ${ }^{14} \mathrm{C}$ ages will be too old. Lake Lisan had a density-layered structure, which was stabilized by freshwater addition to the lake. Stein et al. (1997) showed that the aragonite precipitated from the upper fresh water-rich layer, which was in contact with the atmosphere. They interpreted thick sequences of laminated aragonite and detritus throughout the section as signifying significant intervals with a stable stratification. For a first order approximation of the ${ }^{14} \mathrm{C}$ composition of Lake Lisan surface layer, Schramm et al. (2000) used the Dead Sea and incoming freshwater as an analog.

A surface sample taken in December 1977 had a ${ }^{14} \mathrm{C}$ activity of $108 \%$, slightly lower than the atmospheric value of $122 \pm 2 \%$ measured above Rehovot (Carmi et al. 1985), and implying a reservoir age of about 1000 yr. Reported "ages" of runoff water from the Judean Hills, draining mainly Mesozoic carbonate terrain west of the Dead Sea, and normalized to the atmospheric value of $122 \pm 2 \%$ measured above Rehovot, range as high as 2900 BP, but are more generally between 600-1800 BP (Talma et al. 1997). A Dead Sea sample was taken in December 1977 when the lake had a stratified configuration, as well as water entering the Jordan River from Lake Kinneret (the Sea of Galilee). Both show elevated ${ }^{14} \mathrm{C}$ levels of about $107 \%$, corresponding to ${ }^{14} \mathrm{C}$ ages of $1000 \mathrm{yr}$.

Based on these data, Schramm et al. (2000a) used a reservoir correction of $1000 \mathrm{yr}$ for the aragonite ${ }^{14} \mathrm{C}$. The validity of this correction is supported by the agreement between the Lisan aragonite ${ }^{14} \mathrm{C}$ - 
calendar age calibration with the coral calibration (Bard et al. 1998) back to $23.5 \mathrm{ka}$ cal BP (Figure 1). Data on organic remains over the range of $34-38 \mathrm{ka}$ cal BP are consistent with this correction, although these samples have larger errors.

\section{DISCUSSION}

\section{Comparisons with Other Data Sets}

Two recent efforts to calibrate ${ }^{14} \mathrm{C}$ ages at high resolution have been published by Kitagawa and van der Plicht (1998) and Voelker et al. (1998). Both use non-radiometric methods to generate a chronology.

Kitagawa and van der Plicht (1998) obtained a high-resolution ${ }^{14} \mathrm{C}$ age record of macrofossils (leaves, twigs, and insect wings) from Lake Suigetsu, Japan, using laminated sediments from a 75-m continuous core. The laminae reflect deposition of dark clay and seasonal diatom blooms. The calendar timescale is based on laminae counting. Until $11.8 \mathrm{ka}$ cal BP they use a floating chronology matched to the dendrochronology curve, and until $\sim 38 \mathrm{ka}$ calendar ages are determined through varve counting. For older ages, where the laminations are unclear, they assume a constant sedimentation rate. They must assume no hiatus occurs within the sedimentary sequence. Under these conditions, they estimate an accumulated error of $\sim 2000$ years at $40 \mathrm{ka}$ cal BP.

Voelker et al. (1998) generated a high-resolution set of ${ }^{14} \mathrm{C}$ ages on planktonic foraminifera in two North Atlantic cores. The determination of the calendar ages is not based on direct age determinations of the cores, but is based on the assumption that down core planktonic foraminiferal stable isotope variations can be matched to the $\delta^{18} \mathrm{O}$ temperature record of the GISP2 ice core in Greenland, and that changes occurred simultaneously. The ${ }^{14} \mathrm{C}$ ages of the various correlated climatic events were subsequently linked to the GISP 2 chronology, which is based on ice layer counting.

For all these records with ages older than Holocene, where ${ }^{14} \mathrm{C}$ ages can no longer be calibrated with absolute dating by dendrochronology, errors in the calibrated time scale become more significant and larger calendar age uncertainties have to be tolerated. We compared the Lake Lisan data with the other datasets by plotting the $\Delta^{14} \mathrm{C}$ values of the dated samples against their "calendar age" (Figure 1). A higher $\Delta^{14} \mathrm{C}$ value means a higher atmospheric ${ }^{14} \mathrm{C} /{ }^{12} \mathrm{C}$ ratio. When evaluating different records, it is important to consider 1) how the absolute values of the age offsets compare, and 2) independent of the absolute values, how well the patterns match to each other. If the ${ }^{14} \mathrm{C}$ reservoir correction of a data set is incorrect, but the calendar age is correct, its pattern should be parallel to the others, offset to different $\Delta^{14} \mathrm{C}$ values. If the calendar age is systematically incorrect, but the ${ }^{14} \mathrm{C}$ age is either correct or systematically incorrect, the pattern will remain parallel but both calendar ages and the $\Delta^{14} \mathrm{C}$ values will show an offset.

The Lake Lisan and the coral data show remarkable consistency over the interval that overlaps with the nearly continuous coral record to $23.5 \mathrm{ka}$ cal BP. During this interval, the $\Delta^{14} \mathrm{C}$ value is $\sim 400 \%$. The coral data indicate that $\Delta^{14} \mathrm{C}$ value increases to $\sim 600 \%$ by $\sim 30 \mathrm{ka}$ cal BP, and to $\sim 750 \%$ o at 41 ka cal BP. Near these "checkpoints" the Lisan data are within $2 \sigma$ error of the coral data. The $\Delta^{14} \mathrm{C}$ value of $\sim 900 \%$ at $\sim 42 \mathrm{ka}$ cal BP is further supported by ${ }^{234} \mathrm{U}-{ }^{230} \mathrm{Th}$ ages of tufa sandwiching organic material in rock shelters at Catalunya, Spain (Bischoff et al. 1994), and speleothems from South Africa (Vogel and Kronfeld 1997), despite the higher errors in the calendar ages since the UTh ages are determined by $\alpha$-counting. All these studies indicate high $\Delta{ }^{14} \mathrm{C}$ values of $700-900 \%$ at $\sim 41-43 \mathrm{ka}$ cal BP compared with data at $\sim 38 \mathrm{ka}$ cal BP. These high values are observed to occur directly after the Laschamp geomagnetic anomaly, based on recent determinations of its age. This 

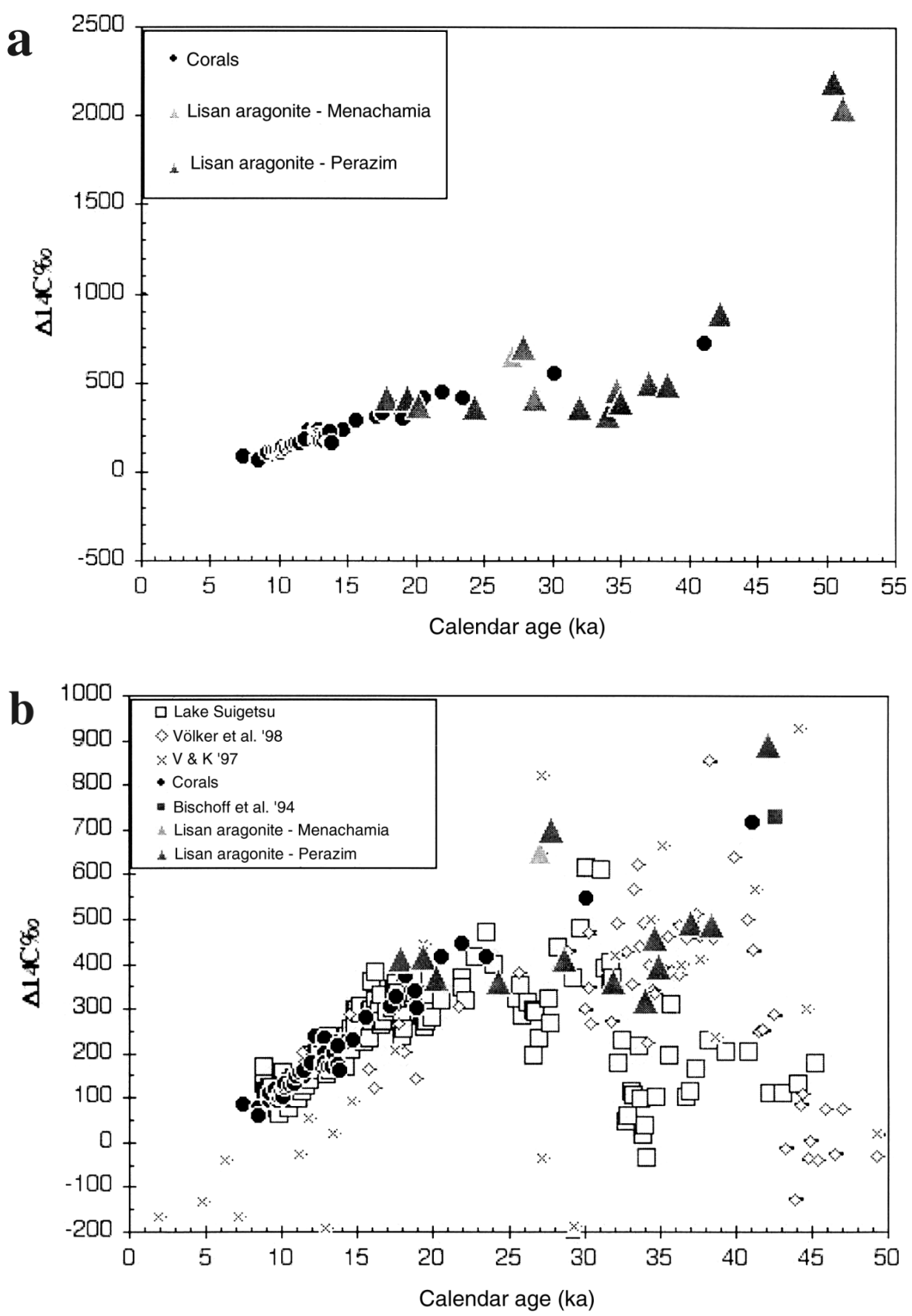

Figure 1 (a) Calendar age (ka cal BP) versus $\Delta{ }^{14} \mathrm{C}$ values in corals (Bard et al. 1998) and Lisan aragonite (this study); (b) Calendar age (ka cal BP) versus $\Delta^{14} \mathrm{C}$ values for all presently available data. Data include the Lisan Formation (this study), corals (Bard et al. 1998), laminated sediments from Lake Suigetsu, Japan (Kitagawa and van der Plicht 1998a, 1998b), North Atlantic planktonic foraminifera (Voelker et al. 1998), cave deposits from South Africa (Vogel and Kronfeld 1997) and tufa from Spain (Bischoff et al. 1994). 
geomagnetic excursion has been recently found within the Lisan section at stratigraphic levels corresponding to $41 \mathrm{ka} \mathrm{cal} \mathrm{BP} \mathrm{(Marco} \mathrm{et} \mathrm{al.} \mathrm{1998;} \mathrm{Ron} \mathrm{et} \mathrm{al.} \mathrm{2000).} \mathrm{The} \mathrm{Laschamp} \mathrm{Event} \mathrm{is} \mathrm{associated}$ with a geomagnetic intensity minimum, causing a higher production of cosmogenic nuclides such ${ }^{14} \mathrm{C}$. Therefore, the paleomagnetic data and the high $\Delta{ }^{14} \mathrm{C}$ observed at this age are consistent with each other.

The Lisan data indicate a sharp decrease in the $\Delta^{14} \mathrm{C}$ value between 41 and $38 \mathrm{ka}$ cal BP to $\sim 450 \%$, consistent with a decrease in ${ }^{14} \mathrm{C}$ production following the geomagnetic excursion. During the interval $38-32 \mathrm{ka}$ cal $\mathrm{BP}$ the Lisan $\Delta^{14} \mathrm{C}$ values show a small decrease to $\sim 350 \%$. There are indications for structure in the ${ }^{14} \mathrm{C}$-calendar age variations. An apparent excursion to high $\Delta^{14} \mathrm{C}$ values of $>600 \%$ o between 28 and $29 \mathrm{ka} \mathrm{cal} \mathrm{BP}$ is found in two samples from widely separated locations: the measured and described section in Perazim Valley in the south and Menahemya near Lake Kinneret (Schramm et al. 2000a). This might be related to the Mono Lake geomagnetic excursion, dated at 28 ${ }^{14} \mathrm{C}$ ka BP (Liddicoat 1992). However, this excursion has not been found globally. We are currently investigating whether the Mono Lake Event is reflected also in the Lisan sediments. Although the Lisan record effectively maps out the large-scale features of ${ }^{14} \mathrm{C}$ age changes throughout the interval 23.5-42 ka cal BP, the resolution of Lisan ${ }^{14} \mathrm{C}$ dates is still too low to make firm conclusions about short-term fluctuations in the atmospheric ${ }^{14} \mathrm{C} /{ }^{12} \mathrm{C}$ ratio.

Comparison of the different data sets yields the following relations (Figure 1):

1. Between 30 and $20 \mathrm{ka}$ cal BP they generally show good agreement. An exception is at 27-28 ka cal BP. The high $\Delta{ }^{14} \mathrm{C}$ values of the Lisan aragonite at this age agrees with a South African cave date. However, they are not observed in the Lake Suigetsu record, which shows an apparent short-term $\Delta^{14} \mathrm{C}$ decrease. There are few North Atlantic foraminifera data within this age interval.

2. Between 38 and $33 \mathrm{ka} \mathrm{cal} \mathrm{BP}$, the North Atlantic foraminifera and Lake Lisan aragonites show high $\Delta^{14} \mathrm{C}$ values of $300-700 \%$. The few South African speleothem data generally agree. However, the high resolution Lake Suigetsu data are much lower, remaining within 100-200\% from the equiline from the end of the record at $\sim 45 \mathrm{ka}$ cal BP through this age interval. The low $\Delta^{14} \mathrm{C}$ values suggest that the Lake Suigetsu calendar ages throughout this interval are underestimated. Indeed, Kitagawa and van der Plicht (1998a) note that the Lake Suigetsu data beyond $31 \mathrm{ka}$ cal BP are inconsistent with other calibrations, and that the ages above $20 \mathrm{ka}$ cal BP should be considered as minimum ages due to the possibility of missing varves. The assumption of a constant sedimentation rate for ages older than $38 \mathrm{ka}$ cal BP is likely to introduce additional uncertainties.

3. From 43 to $53 \mathrm{ka} \mathrm{cal} \mathrm{BP}$, the North Atlantic $\Delta^{14} \mathrm{C}$ values are low, generally close to the equiline. Two Lisan aragonites show an consistent age offsets of $>2000 \%$ at $\sim 51-52 \mathrm{ka}$ cal BP. Comparable calendar $/{ }^{14} \mathrm{C}$ age differences have been found in Labrador Sea cores, but have been attributed to ${ }^{14} \mathrm{C}$ contamination (Guyodo and Valet 1996; Stoner et al. 1995). A ${ }^{14} \mathrm{C}$ age of $50 \mathrm{ka} \mathrm{cal}$ BP corresponds to more than 9 half-lives, and we consider the data on $>43 \mathrm{ka}$ cal BP samples as yet unconfirmed. Nevertheless, it is intriguing that an anomaly in the paleomagnetic direction was identified in the Lisan sediments at 51-52 ka (termed by Marco et al. 1998 as the Lisan geomagnetic event). The only other report of an excursion at this time is from a study in the Gulf of California (Levi and Karlin 1989), which attributed it to the Laschamp Event. The possibility that an increase in ${ }^{14} \mathrm{C}$ production occurred at this time will require further confirmation. 


\section{CONCLUSION}

In view of the central role of ${ }^{14} \mathrm{C}$ ages for a late Pleistocene geochronology, more studies are necessary to establish the changing patterns in atmospheric ${ }^{14} \mathrm{C} /{ }^{12} \mathrm{C}$ ratios, and their relationship to climate, ocean circulation, magnetic field intensity, and solar flux changes. Comparison of the available data calibrating ${ }^{14} \mathrm{C}$ ages beyond $\sim 20 \mathrm{ka}$ cal BP shows a broad agreement between records to $\sim 31 \mathrm{ka} \mathrm{cal} \mathrm{BP}$ and disagreements between the available records from 30 to $50 \mathrm{ka}$ cal BP. A recent paleomagnetic study of the Lisan Formation suggests that a high ${ }^{14} \mathrm{C}$ activity at $\sim 41 \mathrm{ka}$ cal $\mathrm{BP}$ is the result of increased production associated with the Laschamp paleomagnetic excursion event at 43$40 \mathrm{ka}$ (Marco et al. 1998).

Despite the significant progress in the documentation of variations in the atmospheric ${ }^{14} \mathrm{C}$ activity, many open questions remain and call for further detailed study. Will the high age offset at $\sim 50 \mathrm{ka} \mathrm{cal}$ $\mathrm{BP}$, as observed in two Lisan samples, be confirmed by additional data? Is there any relationship to the geomagnetic excursion observed in Lisan Formation at 51 ka cal BP Marco et al. (1998), at present only observed in Lake Lisan and possibly the Gulf of California records? What is the highresolution structure of the changes in atmospheric ${ }^{14} \mathrm{C}$ activity earlier than $24 \mathrm{ka}$ cal BP? Do the high $\Delta^{14} \mathrm{C}$ values seen in two Lake Lisan aragonites at $\sim 27 \mathrm{ka}$ cal BP indicate a short-term increase in atmospheric ${ }^{14} \mathrm{C} /{ }^{12} \mathrm{C}$ ratios, and might it be associated with the Mono Lake geomagnetic event? Lake Lisan sediments, for which radiometric ages, paleomagnetic and paleoclimatic data can be combined, are excellent candidates to address these questions, and have great potential for further establishing a high resolution history of ${ }^{14} \mathrm{C} /{ }^{12} \mathrm{C}$ variations beyond $20 \mathrm{ka}$ cal BP. Comparisons between this record and other excellent records will be needed in the coming few years to resolve the open issues.

\section{ACKNOWLEDGMENTS}

This work is part of the "Lisan project", which has been funded by grants from the German-Israeli Foundation for Scientific Research and Development (GIF grant \#332), the US-Israel Binational Science Foundation (BSF grant \#96-227), and the Israeli Science Foundation (ISF grant \#694.95).

\section{REFERENCES}

Bard E, Hamelin B, Fairbanks RG, Zindler A. 1990. Calibration of the ${ }^{14} \mathrm{C}$ timescale over the past 30,000 years using mass spectrometric U-Th ages from Barbados corals. Nature 345:405-10.

Bard E, Arnold M, Hamelin B, Tisnerat-Laborde N, Cabioch G. 1998. Radiocarbon calibration by means of mass spectrometric ${ }^{230} \mathrm{Th} /{ }^{234} \mathrm{U}$ and ${ }^{14} \mathrm{C}$ ages of corals. An update data base including samples from Barbados, Mururoa and Tahiti. Radiocarbon 40(3):1085-92.

Becker B, Kromer B. 1991. Dendrochronology and radiocarbon calibration of the early Holocene. In: Barton N, Roberts AJ, Roe DA, editors. The Late Glacial in north-west Europe. p 22-4.

Bischoff JL, Fitzpatrick JA. 1991. U-series dating of impure carbonates: an isochron technique using totalsample dissolution. Geochemica et Cosmochemica Acta 55:543-54.

Bischoff JL et al. 1994. Dating of the Basal Aurignacian Sandwich at Abric Romani (Catalunya, Spain) by radiocarbon and uranium- series. Journal of Archeological Science 21:541-51.

Björck S et al. 1996. Synchronized terrestrial-atmosphere deglacial records around the North Atlantic.
Science 274:1155-60.

Burr GS, Beck JW, Taylor FW, Récy J, Edwards RL, Cabioch G, Corrège T, Donahue DJ, O’Malley JM. 1998. A high-resolution radiocarbon calibration between 11,700 and 12,400 calendar years BP derived from ${ }^{230} \mathrm{TH}$ ages of corals from Espiritu Santo Island, Vanuatu. Radiocarbon 40(3):1093-105.

Carmi I, Stiller M, Kaufman A. 1985. The effect of atmospheric ${ }^{14} \mathrm{C}$ variations on the ${ }^{14} \mathrm{C}$ levels in the Jordan River system. Radiocarbon 27(2B):305-13.

Chappell J, Polach. 1991. Radiocarbon dating of corals from a 52 meter deep boring in New Guinea. Nature 349:147-9.

Chen JH, Edwards RL, Wasserburg GJ. 1986. ${ }^{238} \mathrm{U},{ }^{234} \mathrm{U}$ and ${ }^{232} \mathrm{Th}$ in seawater. Earth and Planetary Science Letters 80:241-52.

Chen JH, Curran HA, White B, Wasserburg GJ. 1991. Precise chronology of the last interglacial period. ${ }^{234} \mathrm{U}-{ }^{230} \mathrm{Th}$ data from fossil coral reefs in the Bahamas. Geological Society of America Bulletin 103:82-97.

Edwards RL, Chen JH, Wasserburg GJ. 1987. ${ }^{238} \mathrm{U}-{ }^{234} \mathrm{U}-$ ${ }^{230} \mathrm{Th}-{ }^{232} \mathrm{Th}$ systematic and the precise measurement of time in the past 500,000 years. Earth and Planetary 
Science Letters 81:175-92.

Edwards RL, et al. 1993. A large drop in atmospheric ${ }^{14} \mathrm{C} /{ }^{12} \mathrm{C}$ and reduced melting in the Younger Dryas, documented with ${ }^{230} \mathrm{Th}$ ages of corals. Science 260 : 962-8.

Fairbanks RG. 1989. Sea level rise during the last deglaciation as record in Barbados corals. Nature 342:637-42.

Guyodo Y, Valet JP. 1996. Relative variations in geomagnetic intensity from sedimentary records: the past 200,00 years. Earth and Planetary Science Letters 143:23-36.

Hughen KA, et al. 1998. Deglacial changes in ocean circulation from an extended radiocarbon calibration. Nature 391:65-8.

Kaufman A. 1993. An evaluation of several methods for determining ${ }^{230} \mathrm{Th} / \mathrm{U}$ ages in impure carbonates. Geochimica et Cosmochimica Acta 57:2303-17.

Kaufman A, Wasserburg G J, Porcelli D, Bar-Matthews M, Ayalon A. 1998. U-Th isotope systematics from the Soreq cave, israel and climatic correlations. Earth and Planetary Science Letters 156:141-55.

Kitagawa H, van der Plicht J. 1998a. Atmospheric Radiocarbon Calibration to 45,000 yr B.P.: Late Glacial Fluctuations and Cosmogenic Isotope Production. Science 279:1187-90.

Kitagawa H, van der Plicht J. 1998b. A 40,000 year varve chronology from Lake Suigetsu, Japan: extension of the ${ }^{14} \mathrm{C}$ calibration curve. Radiocarbon 40(1):505-15.

Kromer B, Spurk M. 1998. Revision and tentative extension of the tree-ring based ${ }^{14} \mathrm{C}$ calibration. Radiocarbon 35(1):125-36.

$\mathrm{Ku}$ TL, Liang ZC. 1984. The dating of impure carbonates with decay-series isotopes. Nuclear Instruments and Methods in Physics and Research 223:563-71.

Laj C, A Mazaud, Duplessy JC. 1996. Geomagnetic intensity and ${ }^{14} \mathrm{C}$ abundance in the atmosphere and ocean during the past $50 \mathrm{kyr}$. Geophysical Research Letters 23:2045-8.

Levi S, Karlin R. 1989. A sixty thousand year paleomagnetic record from the Gulf of California sediments: secular variation, late Quaternary excursions and geomagnetic implications. Earth and Planetary Science Letters 92:219-33.

Liddicoat JC. 1992. Mono Lake Excursion in Mono Basin, California, and at Carson Sink and Pyramid Lake, Nevada. Geophysical Journal International 108:44252

Luo S, Ku TL. 1991. U- series isochron dating: A generalized method employing total- sample dissolution. Geochemica et Cosmochemica Acta 55:555-64.

Marco S, Ron H, McWilliams M, Stein M. 1998. High resolution secular variation record from Lake Lisan sediments (paleo-Dead Sea). Earth and Planetary Science Letters 161:145-60.

Mazaud AC, Laj E, Bard M, Arnold, Tric E. 1991. Geomagnetic field control of ${ }^{14} \mathrm{C}$ production over the last $80 \mathrm{kyr}$ : implications for the radiocarbon time-scale.
Geophysical Research Letters 18:1885-8.

Richards DA, Beck JW, Donahue DJ, Smart PL, Edwards RL. 1999. Thorium-230 and Carbon - 14 dating of speleothems from the Bahamas: implications for the calibration of the radiocarbon timescale. Proceedings of the 9th Goldschmidt Conference, Boston. p 245.

Ron H, Stein M, Goldstein SL, Marco S. The duration of geomagnetic excursions documented in Lake Lisan sediments (Paleo-Dead Sea). Earth and Planetary Science Letters. Submitted.

Schramm A, Stein M, Goldstein SL. 2000a. Calibration of the ${ }^{14} \mathrm{C}$ time scale to $>40 \mathrm{ka}$ by ${ }^{234} \mathrm{U}-{ }^{230} \mathrm{Th}$ dating of Lake Lisan sediments (last Glacial Dead Sea). Earth and Planetary Science Letters 175:27-40.

Schramm A, Stein M, Goldstein SL. 2000b. ${ }^{234}$ U- ${ }^{230}$ Th dating of Lake Lisan (Paleo-Dead Sea) aragonite by TIMS. Geochimica et Cosmochimica Acta. Submitted.

Stein M, Wasserburg GJ, Aharon P, Chen JH, Zhu ZR, Bloom A, Chappell J. 1993. TIMS U-series dating and stable isotopes of the last interglacial event in Papua new Guinea. Geochimica et Cosmochimica Acta 53: 2541-54.

Stein M, Starinsky A, Goldstein SL, Katz A, Machlus M, Schramm A. 1997. Strontium isotopic, chemical, and sedimentological evidence for the evolution of Lake Lisan and the Dead Sea. Geochimica et Cosmochimica Acta 61:3975-92.

Stiller M, Chung YC. 1984. Radium in the Dead Sea: A possible tracer for the duration of meromixis. Limnology and Oceanography 29:574-86.

Stoner JS, Channell JET, Hillaire-Marcel C. 1995. Late Pleistocene relative geomagnetis paleointensity from the deep Labrador Sea: regional and global correlations. Earth and Planetary Science Letters 134:23752.

Stuiver M, van der Plicht J. 1998. INTCAL98. Radiocarbon 40(3):1041-164.

Talma AS, Vogel JC, Stiller M. 1997. The radiocarbon content of the Dead Sea. The Dead Sea: The lake and its setting. In: Niemi TM, Ben-Avraham Z, Gat JR. editors. Oxford monographs on geology and geophysics 34. Oxford: Oxford University Press. p 171-83.

Tric EJP, Valet P, Tucholka M, Paterne L, Labeyrie F, Guichard L, Tauxe, Fontugne M. 1992. Paleointensity of the geomagnetic field during the last 80,000 years. Journal of Geophysical Research 97(B6):933751. Voelker AHL et al. 1998. Correlation of marine ${ }^{14} \mathrm{C}$ ages from the Nordic seas with the GISP2 isotope record: implications for radiocarbon calibration beyond 25 ka BP. Radiocarbon 40(1):517-34.

Vogel JC, Kronfeld J. 1997. Calibration of radiocarbon dates for the late Pleistocene using U/Th dates on stalagmites. Radiocarbon 39:27-32.

Winograd IJ, Coplen TB, Landwehr JM, Riggs AC, Ludwig KR, Szabo BJ, Kolesar PT, Revesz KM. 1992. Continuous 500,000-year climate record from vein calcites in Devils Hole, Nevada. Science 258:255-60. 